\title{
Environmental DNA analysis needs local reference data to inform taxonomy-based conservation policy - A case study from Aotearoa / New Zealand
}

Paul Czechowski ${ }^{1 a^{*}}$, Michel de Lange ${ }^{2,3, b}$ Michael Heldsinger ${ }^{4 c}$, Will Rayment ${ }^{4,5 d}$, Christopher Hepburn $^{4,5 \mathrm{e}}$, Monique Ladds ${ }^{6 \mathrm{f}}$, and Michael Knapp ${ }^{1,5 \mathrm{~g}}$

${ }^{1}$ Department of Anatomy, University of Otago, PO Box 56, Dunedin 9054, Aotearoa / New Zealand; ${ }^{2}$ Biostatistics Centre, University of Otago, PO Box 56, Dunedin 9054, Aotearoa / New Zealand; ${ }^{3}$ Pacific Edge, 87 Saint David Street, Dunedin 9016, Aotearoa / New Zealand; ${ }^{4}$ Department of Marine Science, University of Otago, PO Box 56, Dunedin 9054, Aotearoa / New Zealand ${ }^{5}$ Coastal People Southern Skies Centre of Research Excellence, University of Otago, PO Box 56, Dunedin 9054, Aotearoa / New Zealand; ${ }^{6}$ Department of Conservation PO Box 10 420, Wellington 6143, Aotearoa / New Zealand. paul.czechowski@otago.ac.nz; ․michel.delange@ posteo.nz;

cmichael.heldsinger@gmail.com; ; ${ }^{\mathrm{d}}$ will.rayment@otago.ac.nz;

党 chris.hepburn@otago.ac.nz; ${ }^{\mathrm{f}}$ mladds@ doc.govt.nz; ${ }^{\mathrm{g}}$ michael.knapp@otago.ac.nz

Running title: eDNA in marine reserves of Aotearoa

Keywords: BRUV, conservation, fish, environmental DNA, marine reserve, visual survey, sharks

Article Type: Perspectives

Number of words: 3195 (Introduction up to and including Acknowledgements)

Number of references: 29

Number of Figures and Tables: $4+1$

Corresponding Author: Paul Czechowski, Department of Anatomy, University of Otago, PO Box 56, Dunedin 9054, Aotearoa / New Zealand; $\begin{array}{llllll}\text { paul.czechowski@otago.ac.nz; } & \text { Phone } & +64 & 021 & 024 & 91263\end{array}$ 


\section{Abstract}

27 Effective management of biodiversity requires regular surveillance of multiple species.

28 Analysis of environmental DNA by metabarcoding (eDNA) holds promise to achieve this 29 relatively easily. However, taxonomic inquiries into eDNA data need suitable molecular 30 reference data, which are often lacking. We evaluate the impact of this reference data void in 31 a case study of fish diversity in the remote fiords of New Zealand. We compared eDNA-

32 derived species identifications against Baited Remote Underwater Video (BRUV) data 33 collected at the same time and locations as the eDNA data. Furthermore, we cross referenced 34 both eDNA and BRUV data against species lists for the same region obtained from literature 35 surveys and the Ocean Biodiversity Information System (OBIS). From all four data sources, 36 we obtained a total of 116 species records (106 ray-finned fishes, 10 cartilaginous fishes; 59 37 from literature, 44 from eDNA, 25 from BRUV, 25 from OBIS). Concordance of taxonomies 38 between the data sources dissolved with lowering taxonomic levels, most decisively so for 39 eDNA data. BRUV agreed with local biodiversity information much better and fared better in 40 detecting regional biodiversity dissimilarities. We provide evidence that eDNA 41 metabarcoding will remain a powerful but impaired tool for species-level biodiversity 42 management without locally generated reference data.

\section{Introduction}

44 Marine reserve (MR) networks conserve biodiversity by stabilizing communities and 45 maintaining food web structure (Wing \& Jack, 2013). Effective management of MR 46 biodiversity requires regular surveillance, for example to avoid overexploitation by fishing 47 (Wing \& Jack, 2013), or to avoid damage through influx of non-indigenous species 48 (Cunningham, 2019). Fish surveillance is of particular interest due to their sensitivity to most 49 forms of human disturbance, their usefulness at all levels of biological organization, and the 50 favourable benefit-to-cost ratio of fish assessment programmes (Harris, 1995).

51 Analysis of environmental DNA (eDNA) metabarcoding data is a well-established molecular 52 technique for multispecies surveys (Cristescu \& Hebert, 2018). Environmental DNA 53 metabarcoding holds promise for biodiversity surveys intended to inform biodiversity 54 management - associated techniques are regarded more cost-efficient than traditional 55 methods (such as baited remote underwater video surveys - BRUV), less dependent on expert 56 taxonomic knowledge, can be standardized, and are able to inform on a broad range of taxa 57 (Sigsgaard et al., 2020). 
58 Reliable low-level taxonomic annotation is a prerequisite for useful biodiversity management

59 and biological surveillance (e.g., Jack \& Wing 2013). For example, in a southern New

60 Zealand context, Parapercis colias (blue cod) is of high commercial interest, but three other

61 of the 79 cod species are known from New Zealand (Roberts et al., 2019), so that genus

62 information alone is ambiguous for determining blue cod presence or absence. Accordingly,

63 higher-level taxonomic classifications (e.g., family, and order levels) are even less

64 informative for species level conservation management. This reality translates into the desire

65 for obtaining perfect 100 bp to 200 bp alignments (Huson et al. 2007) between an unknown

66 eDNA-derived query sequence and a well described reference sequence derived from a valid

67 species. In practice, absence of such reference data necessitates relaxation of taxonomy-

68 assigning alignment parameters to retain sufficient eDNA data for analysis, and in

69 consequence the data's informative quality suffers.

70 Availability of suitable reference data for metabarcoding is highly variable depending on

71 taxonomic groups and geographic locations, with fish considered relatively well covered in

72 Barcode of Life Data Systems (BOLD) and NCBIs GenBank (Benson et al. 2011) for some

73 regions such as Europe (Weigand et al., 2019). Arguably, fewer reference data are available

74 for fish of southern New Zealand. For example, for six commonly used 12S primer pairs,

75 recognized as well suitable for fish multispecies surveys (Weigand et al., 2019), an average

76 of $36 \%$ of all northern European fish species are available as reference data, but only $26 \%$ of

77 southern New Zealand species (GAPeDNA v1.0.1 web interface, 11-Sep-2021; Marques et

78 al. 2021; also see SI Table 1).

79 In this study, we evaluate the impact of taxonomic data limitations on multispecies surveys

80 using the example of fish in the UNESCO World Heritage Site Te Wahipounamu (Fiordland)

81 in southern New Zealand. We compare the results of concurrent eDNA and BRUV surveys

82 and cross-reference these data against species lists for the same region obtained from

83 literature and the Ocean Biodiversity Information System (OBIS). The fish diversity of Te

84 Wahipounamu has been described based on a diverse range of mostly visual methods. If our

85 BRUV and eDNA approaches work optimally, we should see a strong overlap between these

86 field data and previously described fish diversity records of the region.

\section{Methods}

88 For this study, we evaluated the presence of Actinopterygii (ray-finned fishes) and 89 Chondrichthyes (cartilaginous fishes) species in one MR, two commercial exclusion zones 
90 (all "MR"), and corresponding control areas in southern Te Wahipounamu, New Zealand

91 (west coast, approximately from -44.3 to -46.25 Southern latitude; Fig. 1a). We obtained and 92 analysed eDNA and BRUV data as well as electronic records proximate to the field work 93 area from the Ocean Biodiversity Information System (OBIS; Ausubel 1999). Furthermore, a 94 reference list of ray-finned fishes and cartilaginous fishes that have been observed in 95 Fiordland was assembled from literature. All observations were formalized using NCBI 96 taxonomy (Federhen, 2012), including trivial names, and limited to classes Actinopterygii 97 and Chondrichthyes.

98 Literature data, itself obtained using various methods, were extracted from five sources, 99 including one meta-analysis (SI Table 2). OBIS data were downloaded for a $38 \mathrm{~km}$ radius 100 around all field work sites (centre point $\mathrm{W} 166.89^{\circ}, \mathrm{S}-45.80^{\circ}$ ), as well as for smaller areas surrounding individual field work sites, (2.5 km radius; Fig. 1a).

102 For a detailed description of field and laboratory work please refer to SI. For eDNA 103 collection and BRUV filming we visited three locations in southern Te Wahipounamu 104 (Moana Uta / Wet Jacket Arm, Taumoana / Five Fingers, and Te Tapuwae a Hua / Long 105 Sound; henceforth WJ MR, FF MR, and LS MR), and accompanying control areas outside 106 those MRs (henceforth WJ CTRL, FF CTRL, and LS CTRL), from 12.-22. December 2019 107 (Fig. 1a.) Within each sampling location, at randomised sites, we collected eDNA (mean 108 depth 14.05 m, med.: 15, sd.: $1.4 \mathrm{~m}$ ), and subsequently deployed BRUV assemblies (mean 109 depth $15.6 \mathrm{~m}$, med.: 16, sd.: $2.6 \mathrm{~m}$; SI). We considered data from 21 sites (FF: 2 FF MR and 1103 FF CTRL, WJ: 4 WJ MR and 4 WJ CTRL, and LS: 4 LS MR and 4 LS CTRL). We 111 collected two $900 \mathrm{ml}$ water samples with eDNA at each site, filtered them alongside negative 112 controls, then sealed and stored them until further processing. BRUV footage was obtained 113 for one hour and analysed by eye.

114 Environmental DNA was isolated in a PCR-free facility alongside extraction and cross115 contamination controls (SI: four species of tropical freshwater fish). After in silico PCR (SI), 116 we amplified our extracts with the well-established and widely used 12S MiFish primers 117 ("MiFish-U"; Miya et al. 2015; see SI Table 1 for primer comparison), targeting 118 Actinopterygii. Chondrichthyes were targeted with slightly altered derivatives ("Elas02", 119 Taberlet et al. 2018). Our single-step PCRs were cycled 45 times, with annealing 120 temperatures of $45{ }^{\circ} \mathrm{C}$ (MiFish-U) or $40{ }^{\circ} \mathrm{C}$ (Elas02). Amplified eDNA was then pooled, 121 visualised, purified, combined equimolarly, diluted to $4.5 \mathrm{pmol}$, and sequenced on an 122 Illumina MiSeq (Illumina, San Diego, US-CA; kit v2, 300 cycles, single-ended). 
123 We defined Amplicon Sequence Variants (ASVs; Callahan et al. 2017) from eDNA after

124 demultiplexing with Cutadapt v3.0 (Martin, 2011), using Qiime2 2020-08 (Bolyen et al.,

125 2019) and DADA2 1.10.0 (Callahan et al., 2016). To yield high quality sequence data we did 126 not allow any mismatches, nor Expected Errors (Edgar \& Flyvbjerg, 2015) during 127 demultiplexing. Taxonomic annotation of denoised data was obtained using Blast 2.10.0+ 128 (Camacho et al., 2009) and a local full copy of the NCBI nucleotide collection (April 2020;

129 Benson et al., 2011) while excluding environmental samples. To yield a maximum of 130 taxonomically annotated ASVs, we chose relaxed taxonomic assignment parameters in 131 combination with an e-value to retain only the most significant alignments. We required a 132 minimum identity of $75 \%$ among all alignments and kept five high-scoring pairs for each 133 eDNA query, each of which needed a minimum coverage of $95 \%$ to be retained. The minimal 134 acceptable e-value was set to $10^{-10}$. We retained the best high-scoring alignment of each 135 query-reference pair based on the highest bit score. We removed data contained in negative 136 controls, alongside ASVs covered by fewer than 15 reads (see SI).

137 To investigate how well the literature- and OBIS-derived biodiversity information were 138 resolved by eDNA and BRUV, we checked the concordance of all data sources on order, 139 family, genus and on species levels. To judge sampling effort and total species diversity 140 based on BRUV and eDNA observations, we inspected species accumulation curves and 141 calculated Good Turing estimators (giving the number of all species based on species already 142 seen in a small sample; Good, 1953), and then compared those values to combined Te 143 Wahipounamu literature and OBIS species records.

144 To verify the credibility of eDNA information, we checked all eDNA species lists against a 145 comprehensive list of all New Zealand fish (Roberts et al., 2019) and evaluated species 146 assignment and alignment qualities.

147 To investigate how useful BRUV, eDNA and OBIS records are in detecting regional 148 differences between fish biodiversity, we used Analysis of Similarity (ANOSIM; Clarke 149 1993). Thereby analysing Jaccard distances (Jaccard, 1912), we looked for significant 150 differences in taxon (species, genus, family, order) overlap depending on various factor 151 combinations, hence checking whether a particular observation method fared better in 152 detecting taxon composition differences either between different field work areas (WJ, FF, 153 LS), or according to protection status (MR or CNTRL). 


\section{Results}

155 Each of our four data sources yielded different species counts. In total, we yielded 116 156 species (106 Actinopterygii, 10 Chondrichthyes), comprised of 59 species from previously 157 published Te Wahipounamu works, 44 unique species derived from eDNA, 25 from BRUV 158 and 25 from OBIS (large area; see Table 1, Fig. 2, SI. Table 4). While 21 field work sites 159 (Fig. 1a) yielded environmental DNA and BRUV data (Fig. 1b, c) matching local OBIS data 160 could only be obtained for nine field work sites (Fig. 1a, small circles, LS CNTRL, FF, WJ), 161 and hence those finer scaled OBIS data were later excluded from ANOSIM as incomplete 162 data (Fig. 1a, small circles, Fig. 1d). For further comparisons with Good-Turing estimates, we 163 posit the local "real" species count to 68 as the number of unique species observed across 164 literature and OBIS (Fig. 3).

165 Obtaining community composition comparable to literature and OBIS data within our works' 166 spatial constraints worked better with BRUV than with eDNA. Nineteen out of 25 species 167 detected with BRUV (76\%) were contained in the literature or on OBIS, but only one out of 16844 species detected with eDNA (2\%) were contained in Te Wahipounamu-specific literature 169 or OBIS (Fig. 1a, large circle). Concordance of taxonomic information between the four data 170 sources dissolved with lowering taxonomic levels, and most decisively for eDNA data (Fig. 171 3). At species level, only two taxonomic assignments from eDNA matched other data 172 sources, namely Notorynchus cepedianus (broadnose sevengill shark), also found with 173 BRUV, and Aldrichetta forsteri (yellow-eye mullet) also listed in the literature (Fig. 2).

174 BRUV agreed better with available local biodiversity information, with 11 species mentioned 175 both in the literature and OBIS, and eight detected species mentioned in the literature only 176 (Fig. 3). On BRUV we identified six species (Bodianus unimaculatus, Chelidonichthys kumu, 177 Galeorhinus galeus, Mustelus lenticulatus, Notorynchus cepedianus, Scorpaena cardinalis) 178 not mentioned in literature, and not in OBIS, but occurring in New Zealand waters (Roberts 179 et al., 2019). While our plateauing species accumulation curves suggested exhaustive 180 sampling (SI Fig. 5), Good-Turing estimates of eDNA data inferred a presence of 60 species 181 in the study area (assuming 27\% missed after 44 observations), and a presence of 26 species 182 using BRUV (assuming 7\% missed after 25 observations).

183 Alignment qualities associated with taxonomic annotation of eDNA data were variable. 184 Forty-four species assigned among eDNA were defined by 92 ASVs (across 142 185 observations) of which only six yielded flawless alignments with reference data (i.e. 14\%, 186 with full query coverage, no alignment gaps). Eighty-six ASVs had variable query coverage 
187 (37 families, Tab. 1 and SI), while 32 ASVs had variable gap counts (15 families, Tab. 1 and

188 SI). Mean query coverage was $93.2 \%$ (min: 78.6\%, med: 97\%, sd 6.5\%), mean gap count was

1891 (max: 10, med: 0, sd 1.83; Tab. 1). Nineteen species assignments among eDNA (43\%) had

190 not been observed in New Zealand, and none of these species were found using BRUV,

191 across literature, or OBIS data (apart from Bovichtus variegatus - thornfish, not in Roberts et

192 al., 2019, but in Roberts, 2005; Fig. 2). Importantly, 25 species observed with eDNA (56.8\%

193 of eDNA-observed species) were known from somewhere New Zealand (Roberts et al., 2019)

194 but were not observed in BRUV or found in Te Wahipounamu literature. Interestingly, using

195 eDNA, we obtained perfect alignments between few ASVs and reference data for

196 Arctocephalus forsteri (New Zealand fur seal), Balaenoptera musculus (blue whale), and

197 Tursiops truncatus (bottlenose dolphin).

198 In ANOSIM, only BRUV data, and not eDNA data, exhibited location-specific differences 199 among species' presence overlaps among the 21 sites - on species, genus, family, and order

200 levels. Significant differences were calculated in overlaps between the six field work areas 201 but not between marine reserve nor control areas (SI Table 3).

202 Investigation of the strikingly homogenous structure of eDNA data by regression analysis of 203 the 142 non-unique eDNA observations (Tjur's $R^{2}$ 0.027) suggested each additional 204 alignment gap to be associated with a $39 \%$ increased probability of observing a non-native 205 species (Odds Ratio 1.39, 95\% CI from 1.19 to 1.66, $p<0.01$ ). A 1\% increase in alignment 206 concordance was associated with a 7\% increased probability of non-native observation (OR 207 1.07, 95\% CI 1.03-1.12, $p<0.01$ ). Null deviance was 572.60 on 141 degrees of freedom, 208 residual deviance was 552.31 on 139 degrees of freedom (SI Figs 7 and 8).

\section{Discussion}

210 What is a realistic estimate of the fish biodiversity in Te Wahipounamu? Based on literature 211 and OBIS alone, we estimate the currently described combined ray-finned and cartilaginous

212 fish species count of Te Wahipounamu to be 68, minding that we constrained OBIS data to 213 surround field sites (Fig. 1, large circle), and that those data are predominantly based on 214 visual observations (SI Table 2). If species counts obtained from literature and OBIS were 215 close to a real value of 68 , and the same was true for eDNA and BRUV data, both respective 216 Good-Turing estimates would be 68. Our BRUV-based Good-Turing estimate of 26 species 217 diverges strongly from this number. This may have several reasons. Firstly, we only 218 inspected an isolated area in Te Wahipounamu, while the literature describes a larger area. 
219 Secondly, bait in BRUV does not attract all fish for the camera, particularly if deployed at

220 limited depth range, as done here. For eDNA, the Good-Turing estimate of 60 species is more

221 like the literature-inferred species count, but this could be coincidental.

222 How credible are eDNA derived species assignments with currently available reference data?

223 We believe lacking eDNA reference data to restrict accurate species annotation of ASVs.

224 There are several observations from our data that appear to support this hypothesis. First,

225 while there is a reasonably good concordance between species identified in our BRUV

226 analyses and species known from the area as combined from publications and OBIS, the

227 dissimilarity between eDNA data on one side, and BRUV, OBIS and publication data on the

228 other side, increases with decreasing taxonomic level, culminating in only two out of 44

229 eDNA species being either identified in our BRUV analyses or known from previous

230 publications (Fig. 3).

231 Secondly, every approach to identify species diversity in a marine ecosystem has its biases,

232 and published observations are mostly based on visual approaches. Thus, one could argue for

233 the existence of a bias favouring similarity between our visual BRUV observations and

234 published species occurrences to the detriment of eDNA data's similarity. However, we do

235 not believe this circumstance alone to be responsible for a bias favouring BRUV data to be

236 more similar with literature and OBIS observations in comparison to eDNA observations.

237 Literature and OBIS observation methodologies extend well beyond the specific biases of

238 BRUV, including a multitude of different observation techniques (poison stations, seine net

239 fishing, spear fishing, diver surveys and others, SI Table 1). Collectively, all observation

240 techniques should have provided an appropriately comprehensive overview of fish diversity

241 in Te Wahipounamu, lacking biases inherent to BRUV.

242 Thirdly, some divergence between eDNA data and the other data sources may be explained

243 by the known ability of eDNA to detect "cryptic" species that are not easily discovered by

244 any visual surveying. The most obvious candidates for this category would be the 25 eDNA

245 species that had previously been reported from New Zealand but not yet from Te

246 Wahipounamu (Fig. 2). However, such a bias should not prevent a broad overlap between

247 eDNA and visual approaches for species that can easily be detected visually. Clearly, we did

248 not find such an overlap.

249 Crucially, of the 25 species we detected by BRUV and that were therefore present at the time

250 of our concurrent water sampling for eDNA analyses, 24 species are not present in the NCBI 
251 reference database (Fig. 2) and could therefore not be detected by our eDNA approach. This

252 highlights one of the main limitations of eDNA multispecies surveys today.

253 Nevertheless, and despite the lack of reference data, eDNA still identified a larger number of

254 species than our concurrent BRUV analyses. From where do these species assignments

255 come? In most cases during taxonomic assignment, where no perfect match can be found

256 between eDNA query and reference subject sequence, the algorithm assigning ASVs to

257 species information (BLAST) chose the next-closest matching species contained in the

258 reference data collection, as encouraged by our taxonomic assignment parameters. Our

259 taxonomic assignments correspond with this hypothesis, as binomial regression showed that

260 each additional gap in a sequences' reference alignment associated with a 39\% increased

261 probability of observing of a non-native species.

262 Interestingly, a $1 \%$ increase in alignment concordance increased the likelihood of a non-

263 native observation as well, by 7\%. At first sight this seems counter-intuitive, however the

264 latter observation is also consistent with our hypothesis: A poorly matching sequence would

265 not be assigned to a matching species but rather to a higher matching taxon such as genus or

266 family. A better fit increases the likelihood of a species level assignment, but without native

267 species contained among reference data, the likelihood increases that the query sequence is

268 assigned to a closely related species not occurring in New Zealand. Similar observations have

269 been made in other regions of the world (Stoeckle, Das Mishu, \& Charlop-Powers, 2020).

270 The large number of species detected by our eDNA approach - although probably

271 misassigned in several instances - is a testament to the potential power of eDNA methods.

272 Arguably, any detected effect of lacking reference data could be less pronounced by using

273 another, or multiple primer pairs. For example, our primer evaluations with the recently

274 released software GAPeDNA (Marques et al., 2021) show that the "Fish 16S" primer set by

275 McInnes et al. (2017) would have covered 249 instead of the 119 New Zealand marine fish

276 species covered by our MiFish 12S dataset (SI Table 1). However, the overall conclusion

277 remains. Of the over 1294 known New Zealand marine fish species, molecular reference data

278 of any kind is available only for 489 species in southern New Zealand, and for no available

279 primer pairs sufficient reference data is available. Hence without substantial effort into

280 generating suitable reference data for a carefully selected range of similar primers, eDNA

281 analysis here and everywhere else will remain an impaired tool for biodiversity management.

282 While this insight holds true after almost two decades of eDNA research (Hebert, Cywinska,

283 Ball, \& DeWaard, 2003) we note that a growing number of researchers are working hard on 
284 closing reference data voids around the globe (reviewed in Marques et al., 2021; Weigand et 285 al., 2019).

\section{Acknowledgments and Data}

287 Funded in part by the New Zealand Department of Conservation. Authors were supported by 288 the University of Otago. Authorship determination followed the Contributor Roles Taxonomy 289 (https://casrai.org/credit). P.C. lead field, lab and analysis work and wrote manuscript. M.d.L. 290 provided Good-Turing estimates, accumulation curves and advised P.C. M.H., M.L., P.C. 291 obtained, and M.H. viewed BRUV footage. M.H. aided DNA extraction. W.R., C.H., M.K. 292 obtained funding. Everyone contributed to manuscript revision. We appreciate Olga 293 Kardailsky for obtaining deceased aquarium fish, and Anya Kardailsky for helping water 294 filtering (both University of Otago). Sequencing was undertaken by Otago Genomics. Data 295 and code generated for this work are archived at https://doi.org/10.5281/zenodo.4638297.

\section{References}

297 Ausubel, J. (1999). Toward a Census of Marine Life. Oceanography, 12(3), 4-5. doi: 10.5670/oceanog.1999.17

Benson, D. a, Karsch-Mizrachi, I., Lipman, D. J., Ostell, J., \& Sayers, E. W. (2011). GenBank. Nucleic Acids Research, 39(Database issue), D32-7. doi: 10.1093/nar/gkq1079

Bolyen, E., Rideout, J. R., Dillon, M. R., Bokulich, N. A., Abnet, C. C., Al-Ghalith, G. A., ... Caporaso, J. G. (2019). Reproducible, interactive, scalable and extensible microbiome data science using QIIME 2. Nature Biotechnology, 37(8), 852-857. doi: $10.1038 / \mathrm{s} 41587-019-0209-9$

306 Callahan, B. J., McMurdie, P. J., \& Holmes, S. P. (2017). Exact sequence variants should 11(12), 113597. doi: 10.1038/ismej.2017.119 
309 Callahan, B. J., McMurdie, P. J., Rosen, M. J., Han, A. W., Johnson, A. J. A., \& Holmes, S.

310 P. (2016). DADA2: High-resolution sample inference from Illumina amplicon data.

311 Nature Methods, 13(7), 581-583. doi: 10.1038/nmeth.3869

312 Camacho, C., Coulouris, G., Avagyan, V., Ma, N., Papadopoulos, J., Bealer, K., \& Madden,

313 T. L. (2009). BLAST+: Architecture and applications. BMC Bioinformatics, 10(1),

314 421. doi: 10.1186/1471-2105-10-421

315 Clarke, K. R. (1993). Non-parametric multivariate analyses of changes in community 316 structure. Austral Ecology, 18(1), 117-143. doi: 10.1111/j.1442-9993.1993.tb00438.x

317 Cristescu, M. E., \& Hebert, P. D. N. (2018). Uses and Misuses of Environmental DNA in

318 Biodiversity Science and Conservation. Annual Review of Ecology, Evolution, and 319 Systematics, 49(1), 209-230. doi: 10/gfkkjq

320 Cunningham, S. (2019). Mitigating the threat of invasive marine species to Fiordland: New Zealand's first pathway management plan. Management of Biological Invasions,

323 Edgar, R. C., \& Flyvbjerg, H. (2015). Error filtering, pair assembly and error correction for next-generation sequencing reads. Bioinformatics, 31(21), 3476-3482. doi: 10.1093/bioinformatics/btv401

326 Federhen, S. (2012). The NCBI Taxonomy database. Nucleic Acids Research, 40(D1), D136D143. doi: 10/c452q3

328 Good, I. J. (1953). The Population Frequencies of Species and the Estimation of Population 329 Parameters. Biometrika, 40(3/4), 237. doi: 10/d7kccb

330 Harris, J. H. (1995). The use of fish in ecological assessments. Austral Ecology, 20(1), 65-80. 
332 Hebert, P. D. N., Cywinska, A., Ball, S. L., \& DeWaard, J. R. (2003). Biological

333 identifications through DNA barcodes. Proceedings of the Royal Society B:

334 Biological Sciences, 270(1512), 313-321. doi: 10/fnjqv7

335 Huson, D. H., Auch, A. F., Qi, J., \& Schuster, S. C. (2007). MEGAN analysis of 336 metagenomic data. Genome Research, 17(3), 377-386. doi: 10.1101/gr.5969107

337 Inglis, G., MAF Biosecurity New Zealand, Post-border Directorate, \& MAF Biosecurity New 338 Zealand. (2008). Milford Sound: First baseline survey for non-indigenous marine 339 species (research project ZBS2005/19). Wellington, N.Z.: MAF Biosecurity New 340 Zealand. Retrieved from https://niwa.co.nz/static/marine341 biosecurity/Inglis\%20et\%20al\%202008\%20milford\%20resurvey\%20report.pdf

342 Jaccard, P. (1912). The distribution of the flora in the Alpine zone. New Phytologist, 11(2), 343 37-50. doi: 10/fvhsjd

344 Jack, L., \& Wing, S. R. (2013). A safety network against regional population collapse:

345 Mature subpopulations in refuges distributed across the landscape. Ecosphere, 4(5), $346 \quad$ 57. doi: $10.1890 / E S 12-00221.1$

347 Marques, V., Milhau, T., Albouy, C., Dejean, T., Manel, S., Mouillot, D., \& Juhel, J.-B. 348 (2021). GAPeDNA: Assessing and mapping global species gaps in genetic databases 349 for eDNA metabarcoding. Diversity and Distributions. doi: $10.1111 /$ ddi.13142

350 Martin, M. (2011). Cutadapt removes adapter sequences from high-throughput sequencing $351 \quad$ reads. EMBnet.Journal, 17(1), 10. doi: 10.14806/ej.17.1.200

352 McInnes, J. C., Jarman, S. N., Lea, M.-A., Raymond, B., Deagle, B. E., Phillips, R. A., ... 353 Alderman, R. (2017). DNA Metabarcoding as a Marine Conservation and 354 Management Tool: A Circumpolar Examination of Fishery Discards in the Diet of 355 Threatened Albatrosses. Frontiers in Marine Science, 4, 277. doi: 356 10.3389/fmars.2017.00277 
357 Miya, M., Sato, Y., Fukunaga, T., Sado, T., Poulsen, J. Y., Sato, K., ... Iwasaki, W. (2015).

MiFish, a set of universal PCR primers for metabarcoding environmental DNA from Science, 2(7), 150088. doi: 10/gmcj95

Roberts, CD, Stewart, A., Struthers, C., Barker, J., \& Kortet, S. (2019). Checklist of the

Roberts, Clive (Ed.). (2005). Regional diversity and biogeography of coastal fishes on the

Sigsgaard, E. E., Torquato, F., Frøslev, T. G., Moore, A. B. M., Sørensen, J. M., Range, P., biomonitoring of marine habitats. Conservation Biology, 34(3), 697-710. doi: 10/gmcj83

Stoeckle, M. Y., Das Mishu, M., \& Charlop-Powers, Z. (2020). Improved Environmental DNA Reference Library Detects Overlooked Marine Fishes in New Jersey, United States. Frontiers in Marine Science, 7, 226. doi: 10.3389/fmars.2020.00226

Weigand, H., Beermann, A. J., Čiampor, F., Costa, F. O., Csabai, Z., Duarte, S., ... Ekrem, T. (2019). DNA barcode reference libraries for the monitoring of aquatic biota in 
bioRxiv preprint doi: https://doi.org/10.1101/2021.10.22.465527; this version posted October 24, 2021. The copyright holder for this preprint (which was not certified by peer review) is the author/funder, who has granted bioRxiv a license to display the preprint in perpetuity. It is made available under aCC-BY-NC 4.0 International license.

381 Wing, S. R., \& Jack, L. (2013). Marine reserve networks conserve biodiversity by stabilizing

382 communities and maintaining food web structure. Ecosphere, 4(11), art135. doi:

383 10.1890/ES13-00257.1 


\section{Figures and Tables}

a

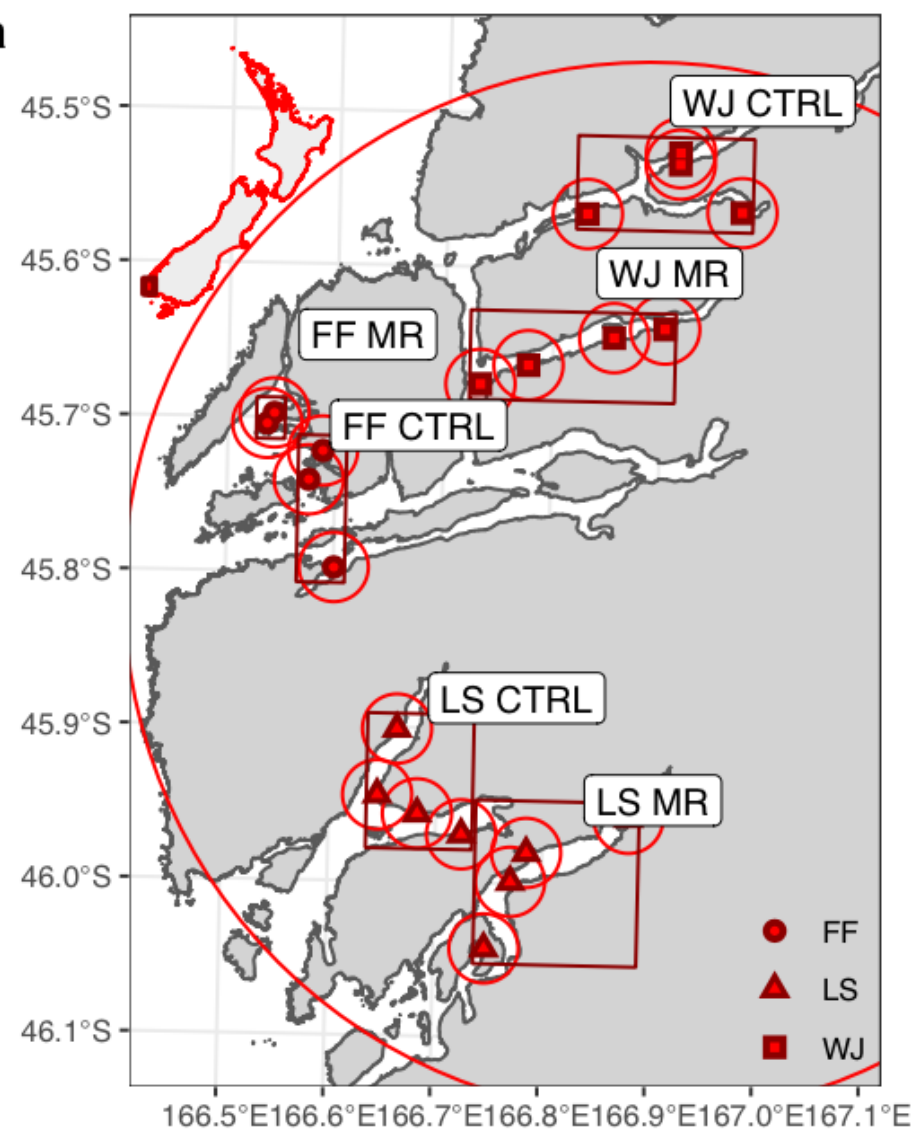

b

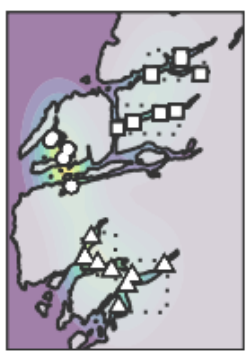

C

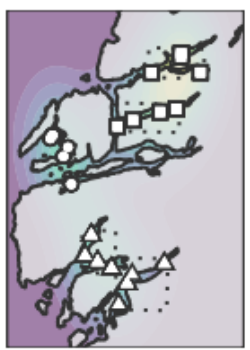

d

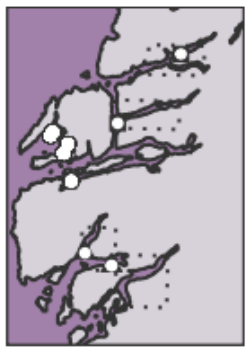

Fig. 1: Field work area, description, sites, and data coverage for eDNA, BRUV, and

OBIS data. a: We obtained biodiversity information from baited remote underwater video (BRUV) footage and environmental DNA (eDNA) data from 21 field work sites across three sampling regions (highlighted by rectangles) - Five Fingers (FF), Long Sound (LS) and Wet Jacket (WJ). In each region we collected samples inside marine reserves / commercial exclusion zones (MR) and outside in control areas (CTRL). To obtain additional biodiversity information, we queried the Ocean Biodiversity Information System (OBIS - https://obis.org/) for records within a $2.5 \mathrm{~km}$ radius of each field work site (small circles) for the purpose of community structure analysis. Furthermore, we obtained OBIS records for the entire sampling region (large circle) to extend our species list alongside species mentioned across various literature sources (Table 1, SI Table 3). b: Environmental DNA (eDNA), and c: BRUV data in a spatial context, lighter colour indicates a higher density of distinct species observations (corresponding to numerical values in Fig. 2). d: Species data for all filed work sites could not be obtained from OBIS, 
bioRxiv preprint doi: https://doi org/10.1101/2021.10.22 465527; this version posted October 24,2021. The copyright holder for this preprint (which was not certified by peer review) is the author/funder, who has granted bioRxiv a license to display the preprint in perpetuity. It is made available under aCC-BY-NC 4.0 International license.

401 necessitating the exclusion of this data in the statistical analyses of regional biodiversity data. Graph created using R package ggplot2 (3.3.5).

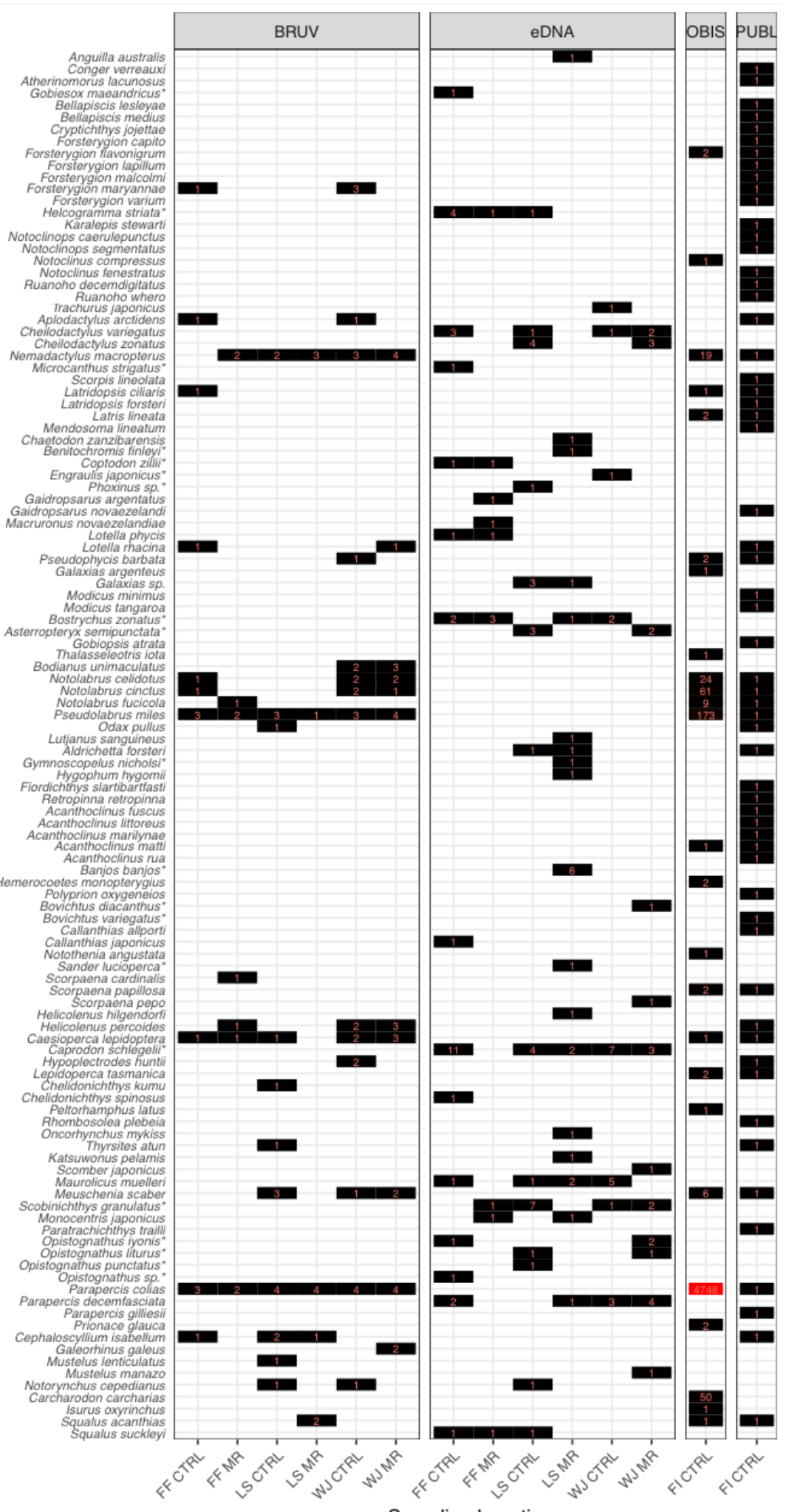


Fig. 2: Distinct species observations across data sources and field work locations. Observation types: BRUV - Observations from baited remote underwater surveys; eDNA - environmental DNA observations; OBIS - data retrieved from the Ocean Biodiversity Information System (https://obis.org/) for the area surrounding field work sites (large circle in Fig.1); PUBL - Fiordland fish species collated from multiple literature records as summarized by Inglis (2008). Sampling Locations: FF - Five Fingers area; LS - Long Sound area; WJ - Wet Jacket area; MR - marine reserve or commercial exclusion zone; CTRL - neither marine reserve nor commercial exclusion zone. Species list: Order follows Table 1, species not listed as New Zealand Species in (CD Roberts et al., 2019) are marked with an asterisk (*). Graph created using R package ggplot2 (3.3.5).

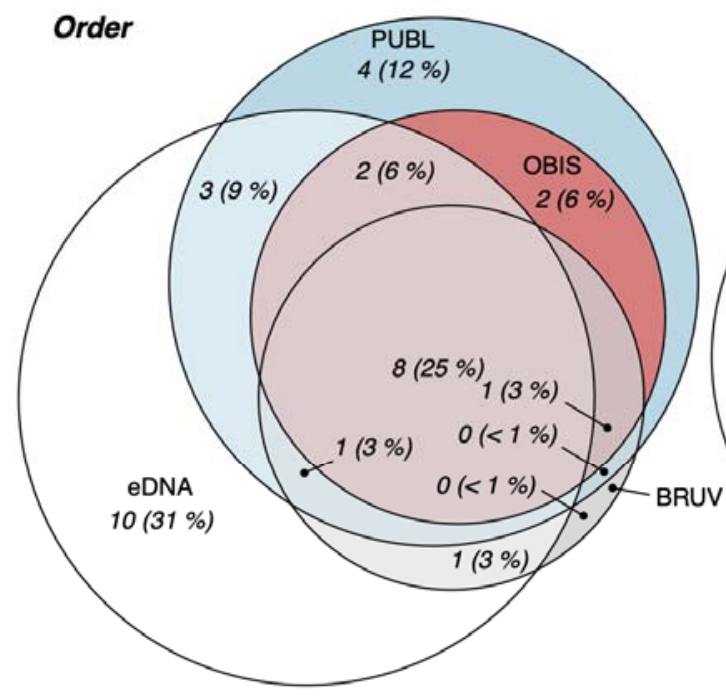

Genus

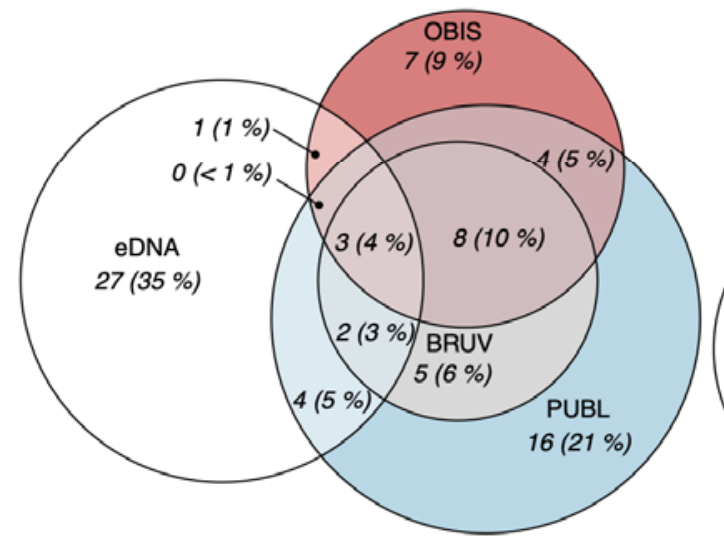

\section{Family}

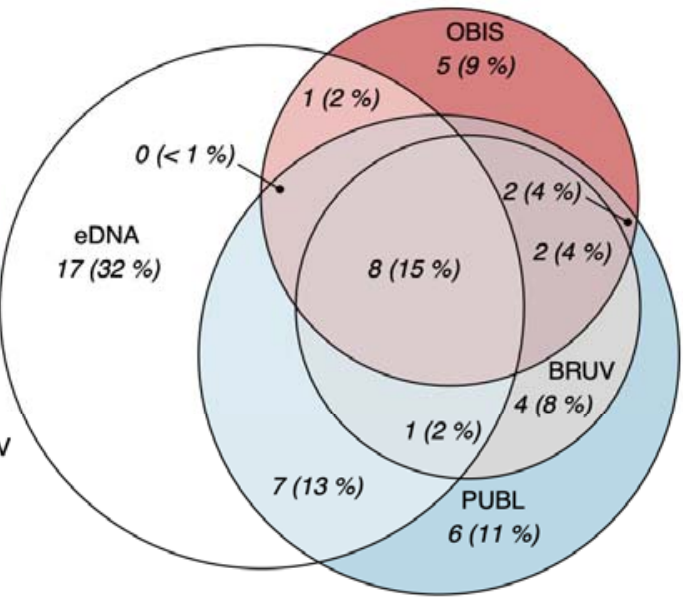

Species

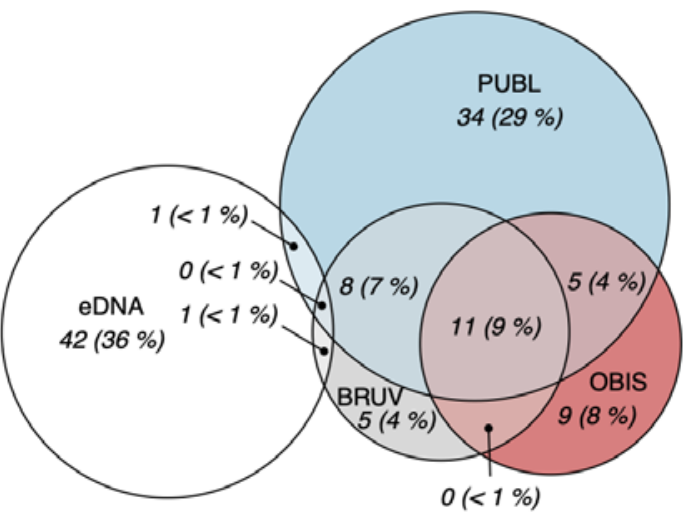

Fig. 3: Concordance of taxonomic information across four data sources of Fiordland fish biodiversity. Biodiversity data (Table 1, SI Table 2) is summarized at four different 
417 taxonomic levels, shown are unique observation counts at each level, as well as the 418 corresponding percentage of those counts in comparison to all data. Circle sizes 419 proportional to observation count. Observation types: BRUV (grey) - Observations from 420 baited remote underwater surveys; eDNA (white) - environmental DNA observations; 421 OBIS (red) - data retrieved from the Ocean Biodiversity Information System 422 (https://obis.org/) for the area surrounding field work sites (large circle in Fig.1); PUBL 423 (blue) - Fiordland fish species collated from multiple literature records as summarized by 424 (Inglis et al., 2008). Graph created using R package eulerr (6.1.0). 
Table 1: Details on taxonomic observations across data sources. Taxonomic hierarchies conform with NCBI taxonomy where available, thus allow analysis in relation to environmental DNA (eDNA) data and are sorted alphabetically - the resulting species order is identical to Fig. 2. Taxa not listed as New Zealand species by Roberts et al., (2019) are highlighted with asterisk (*). Trivial names are indicated where available from NCBI. For all taxonomic assignments also yield from eDNA we provide the alignment coverage and alignment gaps. Since identical species were assigned to multiple Amplicon Sequence Variants (ASV's; Callahan et al., 2017) in some instances, ranges are provided for alignment coverages and gap counts for species-specific alignments. 


\begin{tabular}{|c|c|c|c|c|c|c|c|c|}
\hline Phylum & Class & Order & Family & Genus & Species & $\begin{array}{l}\text { Common } \\
\text { name }\end{array}$ & $\begin{array}{l}\text { Algn. } \\
\text { covrg. }\end{array}$ & $\begin{array}{l}\text { Algn. } \\
\text { gaps }\end{array}$ \\
\hline \multirow[t]{9}{*}{ Chordata } & Actinopteri & Anguilliformes & Anguillidae & Anguilla & Anguilla australis & $\begin{array}{l}\text { Australian } \\
\text { shortfin eel }\end{array}$ & $100 \%$ & 0 \\
\hline & & & Congridae & Conger & Conger verreauxi & conger eel & & \\
\hline & & Atheriniformes & Atherinidae & Atherinomorus & $\begin{array}{l}\text { Atherinomorus } \\
\text { lacunosus }\end{array}$ & $\begin{array}{l}\text { hardyhead } \\
\text { silverside }\end{array}$ & & \\
\hline & & & Tripterygiidae & Bellapiscis & $\begin{array}{l}\text { Bellapiscis } \\
\text { lesleyae }\end{array}$ & $\begin{array}{l}\text { mottled } \\
\text { twister }\end{array}$ & & \\
\hline & & & & & $\begin{array}{l}\text { Bellapiscis } \\
\text { medius }\end{array}$ & twister & & \\
\hline & & & & Forsterygion & $\begin{array}{l}\text { Forsterygion } \\
\text { capito }\end{array}$ & $\begin{array}{l}\text { spotted robust } \\
\text { triplefin }\end{array}$ & & \\
\hline & & & & & $\begin{array}{l}\text { Forsterygion } \\
\text { flavonigrum }\end{array}$ & $\begin{array}{l}\text { yellow-and- } \\
\text { black triplefin }\end{array}$ & & \\
\hline & & & & & $\begin{array}{l}\text { Forsterygion } \\
\text { lapillum }\end{array}$ & $\begin{array}{l}\text { common } \\
\text { triplefin }\end{array}$ & & \\
\hline & & & & & $\begin{array}{l}\text { Forsterygion } \\
\text { malcolmi }\end{array}$ & & & \\
\hline
\end{tabular}




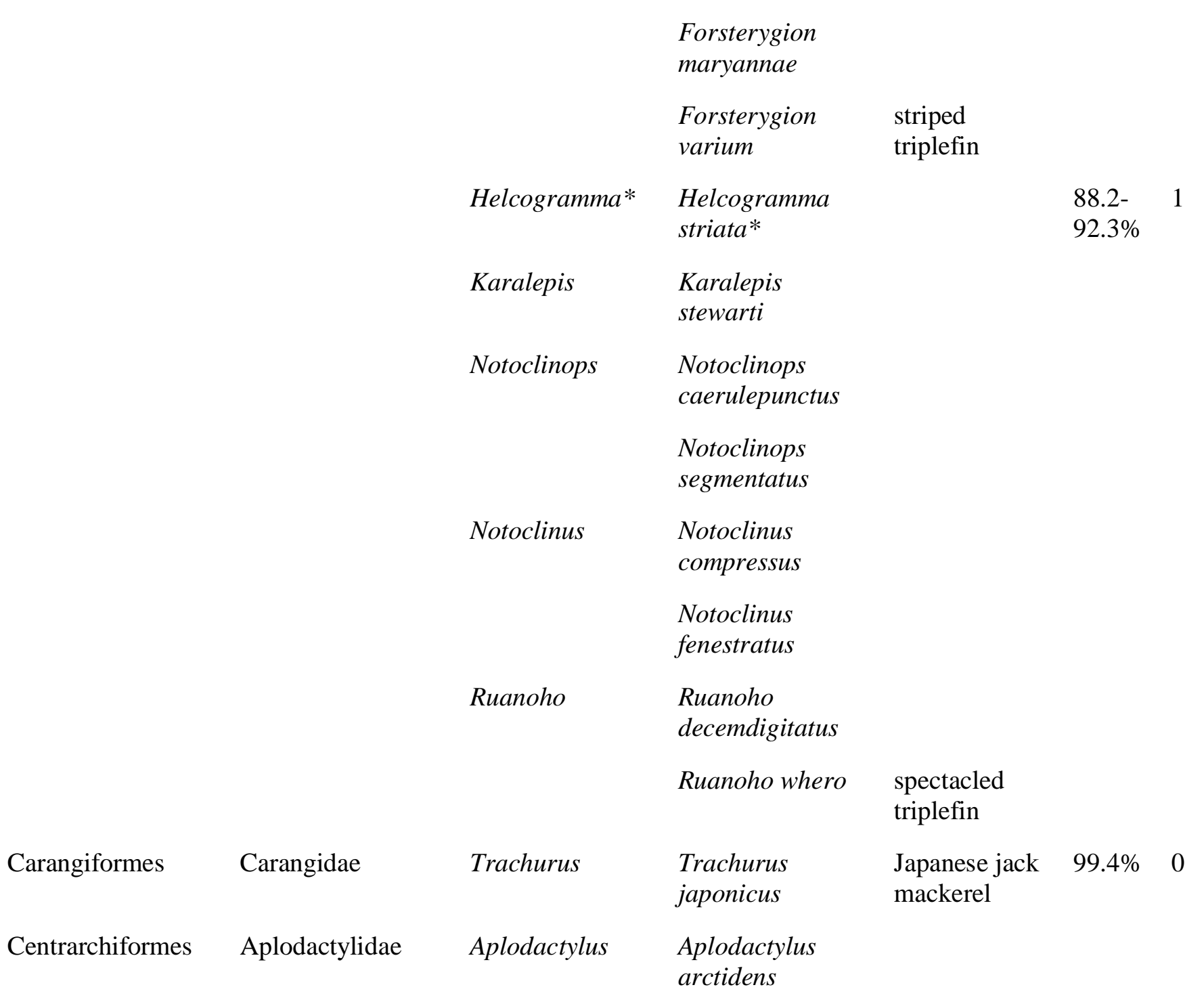




\begin{tabular}{|c|c|c|c|c|c|}
\hline & Cheilodactylidae & Cheilodactylus & $\begin{array}{l}\text { Cheilodactylus } \\
\text { variegatus }\end{array}$ & & $\begin{array}{l}97.6- \\
98.8 \%\end{array}$ \\
\hline & & & $\begin{array}{l}\text { Cheilodactylus } \\
\text { zonatus }\end{array}$ & $\begin{array}{l}\text { blackbarred } \\
\text { morwong }\end{array}$ & $\begin{array}{l}97- \\
97.6 \%\end{array}$ \\
\hline & & Nemadactylus & $\begin{array}{l}\text { Nemadactylus } \\
\text { macropterus }\end{array}$ & tarakihi & \\
\hline & Kyphosidae & Microcanthus* & $\begin{array}{l}\text { Microcanthus } \\
\text { strigatus* }\end{array}$ & stripey & $85.3 \%$ \\
\hline & & Scorpis & Scorpis lineolata & silver sweep & \\
\hline & Latridae & Latridopsis & $\begin{array}{l}\text { Latridopsis } \\
\text { ciliaris }\end{array}$ & blue moki & \\
\hline & & & $\begin{array}{l}\text { Latridopsis } \\
\text { forsteri }\end{array}$ & $\begin{array}{l}\text { bastard } \\
\text { trumpeter }\end{array}$ & \\
\hline & & Latris & Latris lineata & $\begin{array}{l}\text { striped } \\
\text { trumpeter }\end{array}$ & \\
\hline & & Mendosoma & $\begin{array}{l}\text { Mendosoma } \\
\text { lineatum }\end{array}$ & & \\
\hline Chaetodontiformes & Chaetodontidae & Chaetodon & $\begin{array}{l}\text { Chaetodon } \\
\text { zanzibarensis }\end{array}$ & & $81.5 \%$ \\
\hline Cichliformes & Cichlidae & Benitochromis* & $\begin{array}{l}\text { Benitochromis } \\
\text { finleyi* }\end{array}$ & & $79.4 \%$ \\
\hline & & Coptodon* & Coptodon zillii* & $\begin{array}{l}\text { redbelly } \\
\text { tilapia }\end{array}$ & $90.6 \%$ \\
\hline
\end{tabular}




\begin{tabular}{|c|c|c|c|c|c|}
\hline Clupeiformes & Engraulidae & Engraulis* & $\begin{array}{l}\text { Engraulis } \\
\text { japonicus* }\end{array}$ & $\begin{array}{l}\text { Japanese } \\
\text { anchovy }\end{array}$ & $98.8 \%$ \\
\hline Cypriniformes & Cyprinidae & Phoxinus* & Phoxinus sp.* & & $97.1 \%$ \\
\hline \multirow[t]{6}{*}{ Gadiformes } & Gaidropsaridae & Gaidropsarus & $\begin{array}{l}\text { Gaidropsarus } \\
\text { argentatus }\end{array}$ & $\begin{array}{l}\text { Arctic } \\
\text { rockling }\end{array}$ & $90.1 \%$ \\
\hline & & & $\begin{array}{l}\text { Gaidropsarus } \\
\text { novaezelandi }\end{array}$ & & \\
\hline & Merlucciidae & Macruronus & $\begin{array}{l}\text { Macruronus } \\
\text { novaezelandiae }\end{array}$ & blue grenadier & $100 \%$ \\
\hline & Moridae & Lotella & Lotella phycis & & $95.9 \%$ \\
\hline & & & Lotella rhacina & rock cod & \\
\hline & & Pseudophycis & $\begin{array}{l}\text { Pseudophycis } \\
\text { barbata }\end{array}$ & $\begin{array}{l}\text { southern } \\
\text { bastard } \\
\text { codling }\end{array}$ & \\
\hline \multirow[t]{2}{*}{ Galaxiiformes } & Galaxiidae & Galaxias & $\begin{array}{l}\text { Galaxias } \\
\text { argenteus }\end{array}$ & & \\
\hline & & & Galaxias sp. & & $96.5 \%$ \\
\hline \multirow[t]{2}{*}{ Gobiesociformes } & Gobiesocidae & Modicus & Modicus minimus & & \\
\hline & & & $\begin{array}{l}\text { Modicus } \\
\text { tangaroa }\end{array}$ & & \\
\hline Gobiiformes & Eleotridae & Bostrychus* & $\begin{array}{l}\text { Bostrychus } \\
\text { zonatus* }\end{array}$ & $\begin{array}{l}\text { barred } \\
\text { gudgeon }\end{array}$ & $\begin{array}{l}85.4- \\
86 \%\end{array}$ \\
\hline
\end{tabular}




\begin{tabular}{|c|c|c|c|c|c|}
\hline & Gobiidae & Asterropteryx* & $\begin{array}{l}\text { Asterropteryx } \\
\text { semipunctata* }\end{array}$ & starry goby & $\begin{array}{l}81.9- \\
82.5 \%\end{array}$ \\
\hline & & Gobiopsis & Gobiopsis atrata & & \\
\hline & Thalasseleotrididae & Thalasseleotris & $\begin{array}{l}\text { Thalasseleotris } \\
\text { iota }\end{array}$ & & \\
\hline \multirow[t]{6}{*}{ Labriformes } & Labridae & Bodianus & $\begin{array}{l}\text { Bodianus } \\
\text { unimaculatus }\end{array}$ & red pigfish & \\
\hline & & Notolabrus & $\begin{array}{l}\text { Notolabrus } \\
\text { celidotus }\end{array}$ & $\begin{array}{l}\text { New Zealand } \\
\text { spotty }\end{array}$ & \\
\hline & & & $\begin{array}{l}\text { Notolabrus } \\
\text { cinctus }\end{array}$ & & \\
\hline & & & $\begin{array}{l}\text { Notolabrus } \\
\text { fucicola }\end{array}$ & $\begin{array}{l}\text { yellow- } \\
\text { saddled } \\
\text { wrasse }\end{array}$ & \\
\hline & & Pseudolabrus & $\begin{array}{l}\text { Pseudolabrus } \\
\text { miles }\end{array}$ & & \\
\hline & Odacidae & Odax & Odax pullus & greenbone & \\
\hline Lutjaniformes & Lutjanidae & Lutjanus & $\begin{array}{l}\text { Lutjanus } \\
\text { sanguineus }\end{array}$ & $\begin{array}{l}\text { humphead } \\
\text { snapper }\end{array}$ & $80.8 \%$ \\
\hline Mugiliformes & Mugilidae & Aldrichetta & $\begin{array}{l}\text { Aldrichetta } \\
\text { forsteri }\end{array}$ & $\begin{array}{l}\text { yellow-eye } \\
\text { mullet }\end{array}$ & $\begin{array}{l}96- \\
100 \%\end{array}$ \\
\hline Myctophiformes & Myctophidae & Gymnoscopelus* & $\begin{array}{l}\text { Gymnoscopelus } \\
\text { nicholsi* }\end{array}$ & & $79.8 \%$ \\
\hline
\end{tabular}




\begin{tabular}{|c|c|c|c|c|c|}
\hline & & Hygophum & $\begin{array}{l}\text { Hygophum } \\
\text { hygomii }\end{array}$ & & $78.7 \%$ \\
\hline Ophidiiformes & Bythitidae & Fiordichthys & $\begin{array}{l}\text { Fiordichthys } \\
\text { slartibartfasti }\end{array}$ & & \\
\hline Osmeriformes & Retropinnidae & Retropinna & $\begin{array}{l}\text { Retropinna } \\
\text { retropinna }\end{array}$ & cucumberfish & \\
\hline \multirow[t]{5}{*}{ Ovalentaria } & Plesiopidae & Acanthoclinus & $\begin{array}{l}\text { Acanthoclinus } \\
\text { fuscus }\end{array}$ & & \\
\hline & & & $\begin{array}{l}\text { Acanthoclinus } \\
\text { littoreus }\end{array}$ & & \\
\hline & & & $\begin{array}{l}\text { Acanthoclinus } \\
\text { marilynae }\end{array}$ & & \\
\hline & & & $\begin{array}{l}\text { Acanthoclinus } \\
\text { matti }\end{array}$ & & \\
\hline & & & $\begin{array}{l}\text { Acanthoclinus } \\
\text { rua }\end{array}$ & & \\
\hline \multirow[t]{3}{*}{ Pempheriformes } & Banjosidae & Banjos* & Banjos banjos* & & $\begin{array}{l}84.7- \\
85.2 \%\end{array}$ \\
\hline & Percophidae & Hemerocoetes & $\begin{array}{l}\text { Hemerocoetes } \\
\text { monopterygius }\end{array}$ & & \\
\hline & Polyprionidae & Polyprion & $\begin{array}{l}\text { Polyprion } \\
\text { oxygeneios }\end{array}$ & & \\
\hline Perciformes & Bovichtidae & Bovichtus* & $\begin{array}{l}\text { Bovichtus } \\
\text { diacanthus* }\end{array}$ & & $94.1 \%$ \\
\hline
\end{tabular}




\begin{tabular}{|c|c|c|c|c|c|}
\hline & & $\begin{array}{l}\text { Bovichtus } \\
\text { variegatus* }\end{array}$ & thornfish & & \\
\hline \multirow[t]{2}{*}{ Callanthiidae } & Callanthias & $\begin{array}{l}\text { Callanthias } \\
\text { allporti }\end{array}$ & & & \\
\hline & & $\begin{array}{l}\text { Callanthias } \\
\text { japonicus }\end{array}$ & & $95.2 \%$ & 1 \\
\hline Nototheniidae & Notothenia & $\begin{array}{l}\text { Notothenia } \\
\text { angustata }\end{array}$ & Maori chief & & \\
\hline Percidae & Sander* & $\begin{array}{l}\text { Sander } \\
\text { lucioperca* }\end{array}$ & pikeperch & $81.4 \%$ & 3 \\
\hline \multirow[t]{3}{*}{ Scorpaenidae } & Scorpaena & $\begin{array}{l}\text { Scorpaena } \\
\text { cardinalis }\end{array}$ & red rock cod & & \\
\hline & & $\begin{array}{l}\text { Scorpaena } \\
\text { papillosa }\end{array}$ & & & \\
\hline & & Scorpaena pepo & $\begin{array}{l}\text { pumpkin } \\
\text { scorpionfish }\end{array}$ & $85.7 \%$ & 0 \\
\hline \multirow[t]{2}{*}{ Sebastidae } & Helicolenus & $\begin{array}{l}\text { Helicolenus } \\
\text { hilgendorfi }\end{array}$ & & $95.4 \%$ & 0 \\
\hline & & $\begin{array}{l}\text { Helicolenus } \\
\text { percoides }\end{array}$ & & & \\
\hline \multirow[t]{2}{*}{ Serranidae } & Caesioperca & $\begin{array}{l}\text { Caesioperca } \\
\text { lepidoptera }\end{array}$ & & & \\
\hline & Caprodon* & $\begin{array}{l}\text { Caprodon } \\
\text { schlegelii* }\end{array}$ & sunrise perch & $\begin{array}{l}90.6- \\
98.2 \%\end{array}$ & $0-2$ \\
\hline
\end{tabular}




\begin{tabular}{|c|c|c|c|c|c|c|}
\hline & & Hypoplectrodes & $\begin{array}{l}\text { Hypoplectrodes } \\
\text { huntii }\end{array}$ & & & \\
\hline & & Lepidoperca & $\begin{array}{l}\text { Lepidoperca } \\
\text { tasmanica }\end{array}$ & & & \\
\hline & Triglidae & Chelidonichthys & $\begin{array}{l}\text { Chelidonichthys } \\
\text { kити }\end{array}$ & $\begin{array}{l}\text { bluefin } \\
\text { gurnard }\end{array}$ & & \\
\hline & & & $\begin{array}{l}\text { Chelidonichthys } \\
\text { spinosus }\end{array}$ & red gurnard & $99.4 \%$ & 0 \\
\hline Pleuronectiformes & Rhombosoleidae & Peltorhamphus & $\begin{array}{l}\text { Peltorhamphus } \\
\text { latus }\end{array}$ & speckled sole & & \\
\hline & & Rhombosolea & $\begin{array}{l}\text { Rhombosolea } \\
\text { plebeia }\end{array}$ & $\begin{array}{l}\text { New Zealand } \\
\text { flounder }\end{array}$ & & \\
\hline Salmoniformes & Salmonidae & Oncorhynchus & $\begin{array}{l}\text { Oncorhynchus } \\
\text { mykiss }\end{array}$ & rainbow trout & $100 \%$ & 0 \\
\hline Scombriformes & Gempylidae & Thyrsites & Thyrsites atun & snoek & & \\
\hline & Scombridae & Katsuwonus & $\begin{array}{l}\text { Katsuwonus } \\
\text { pelamis }\end{array}$ & skipjack tuna & $95.9 \%$ & 0 \\
\hline & & Scomber & $\begin{array}{l}\text { Scomber } \\
\text { japonicus }\end{array}$ & chub mackerel & $100 \%$ & 0 \\
\hline Stomiiformes & Sternoptychidae & Maurolicus & $\begin{array}{l}\text { Maurolicus } \\
\text { muelleri }\end{array}$ & pearlsides & $\begin{array}{l}86.3- \\
99.4 \%\end{array}$ & $0-10$ \\
\hline Tetraodontiformes & Monacanthidae & Meuschenia & $\begin{array}{l}\text { Meuschenia } \\
\text { scaber }\end{array}$ & $\begin{array}{l}\text { velvet } \\
\text { leatherjacket }\end{array}$ & & \\
\hline
\end{tabular}




\begin{tabular}{|c|c|c|c|c|c|c|c|}
\hline & & & Scobinichthys* & $\begin{array}{l}\text { Scobinichthys } \\
\text { granulatus* }\end{array}$ & $\begin{array}{l}\text { rough } \\
\text { leatherjacket }\end{array}$ & $\begin{array}{l}98.8- \\
99.4 \%\end{array}$ & 0 \\
\hline & \multirow[t]{2}{*}{ Trachichthyiformes } & Monocentridae & Monocentris & $\begin{array}{l}\text { Monocentris } \\
\text { japonicus }\end{array}$ & & $\begin{array}{l}94.4- \\
97.6 \%\end{array}$ & $2-3$ \\
\hline & & Trachichthyidae & Paratrachichthys & $\begin{array}{l}\text { Paratrachichthys } \\
\text { trailli }\end{array}$ & sandpaper fish & & \\
\hline & \multirow[t]{4}{*}{ undefined } & Opistognathidae & Opistognathus* & $\begin{array}{l}\text { Opistognathus } \\
\text { iyonis* }\end{array}$ & & $\begin{array}{l}89.9- \\
90.5 \%\end{array}$ & $2-3$ \\
\hline & & & & $\begin{array}{l}\text { Opistognathus } \\
\text { liturus* }\end{array}$ & seto-amadai & $\begin{array}{l}89.3- \\
90.5 \%\end{array}$ & 2 \\
\hline & & & & $\begin{array}{l}\text { Opistognathus } \\
\text { punctatus* }\end{array}$ & $\begin{array}{l}\text { finespotted } \\
\text { jawfish }\end{array}$ & $81.7 \%$ & 5 \\
\hline & & & & $\begin{array}{l}\text { Opistognathus } \\
\text { sp.* }\end{array}$ & & $85.7 \%$ & 2 \\
\hline & \multirow[t]{3}{*}{ Uranoscopiformes } & Pinguipedidae & Parapercis & Parapercis colias & $\begin{array}{l}\text { New Zealand } \\
\text { blue cod }\end{array}$ & & \\
\hline & & & & $\begin{array}{l}\text { Parapercis } \\
\text { decemfasciata }\end{array}$ & & $80.9 \%$ & 1 \\
\hline & & & & $\begin{array}{l}\text { Parapercis } \\
\text { gilliesii }\end{array}$ & $\begin{array}{l}\text { yellow } \\
\text { weaver }\end{array}$ & & \\
\hline \multirow[t]{2}{*}{ Chondrichthyes } & \multirow[t]{2}{*}{ Carcharhiniformes } & Carcharhinidae & Prionace & Prionace glauca & blue shark & & \\
\hline & & Scyliorhinidae & Cephaloscyllium & $\begin{array}{l}\text { Cephaloscyllium } \\
\text { isabellum }\end{array}$ & & & \\
\hline
\end{tabular}




\begin{tabular}{|c|c|c|c|c|c|c|}
\hline & Triakidae & Galeorhinus & $\begin{array}{l}\text { Galeorhinus } \\
\text { galeus }\end{array}$ & tope shark & & \\
\hline & & Mustelus & $\begin{array}{l}\text { Mustelus } \\
\text { lenticulatus }\end{array}$ & $\begin{array}{l}\text { spotted } \\
\text { estuary } \\
\text { smooth-hound }\end{array}$ & & \\
\hline & & & Mustelus manazo & $\begin{array}{l}\text { starspotted } \\
\text { smooth-hound }\end{array}$ & $98.9 \%$ & c \\
\hline Hexanchiformes & Hexanchidae & Notorynchus & $\begin{array}{l}\text { Notorynchus } \\
\text { cepedianus }\end{array}$ & $\begin{array}{l}\text { broadnose } \\
\text { sevengill } \\
\text { shark }\end{array}$ & $98.4 \%$ & 0 \\
\hline \multirow[t]{2}{*}{ Lamniformes } & Alopiidae & Carcharodon & $\begin{array}{l}\text { Carcharodon } \\
\text { carcharias }\end{array}$ & $\begin{array}{l}\text { great white } \\
\text { shark }\end{array}$ & & \\
\hline & & Isurus & Isurus oxyrinchus & $\begin{array}{l}\text { shortfin mako } \\
\text { shark }\end{array}$ & & \\
\hline \multirow[t]{2}{*}{ Squaliformes } & Squalidae & Squalus & $\begin{array}{l}\text { Squalus } \\
\text { acanthias }\end{array}$ & spiny dogfish & & \\
\hline & & & Squalus suckleyi & $\begin{array}{l}\text { Puget Sound } \\
\text { dogfish }\end{array}$ & $100 \%$ & ( \\
\hline
\end{tabular}


a
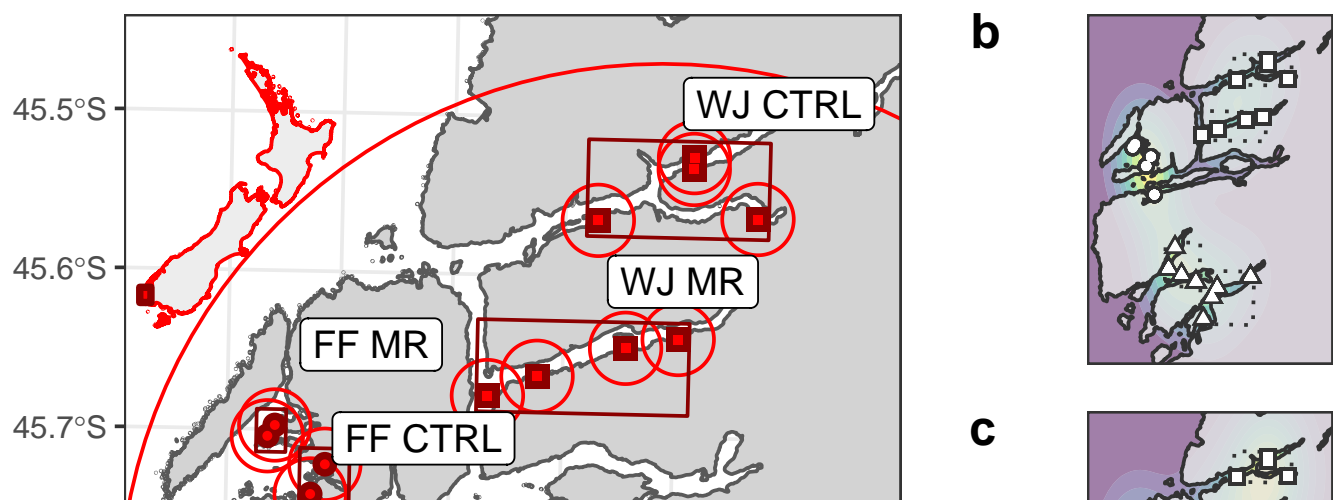

C

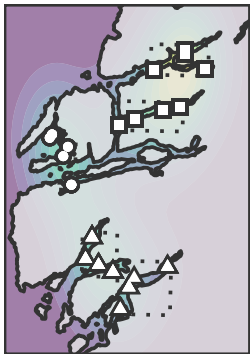

$45.8^{\circ} \mathrm{S}$
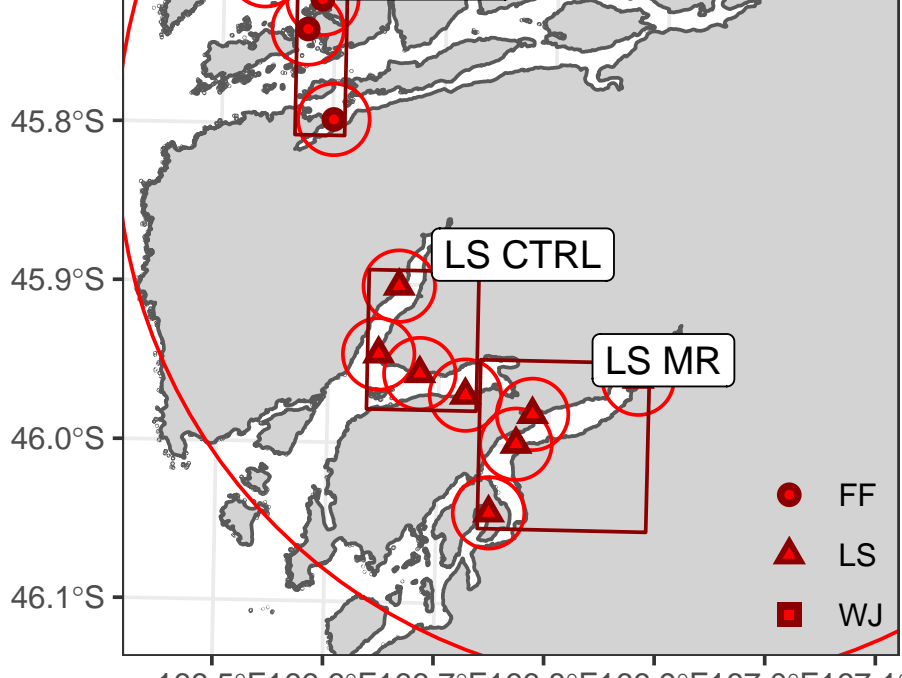

$166.5^{\circ} \mathrm{E} 166.6^{\circ} \mathrm{E} 166.7^{\circ} \mathrm{E} 166.8^{\circ} \mathrm{E} 166.9^{\circ} \mathrm{E} 167.0^{\circ} \mathrm{E} 167.1^{\circ} \mathrm{E}$

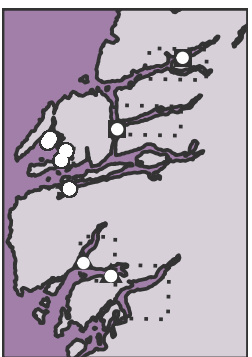




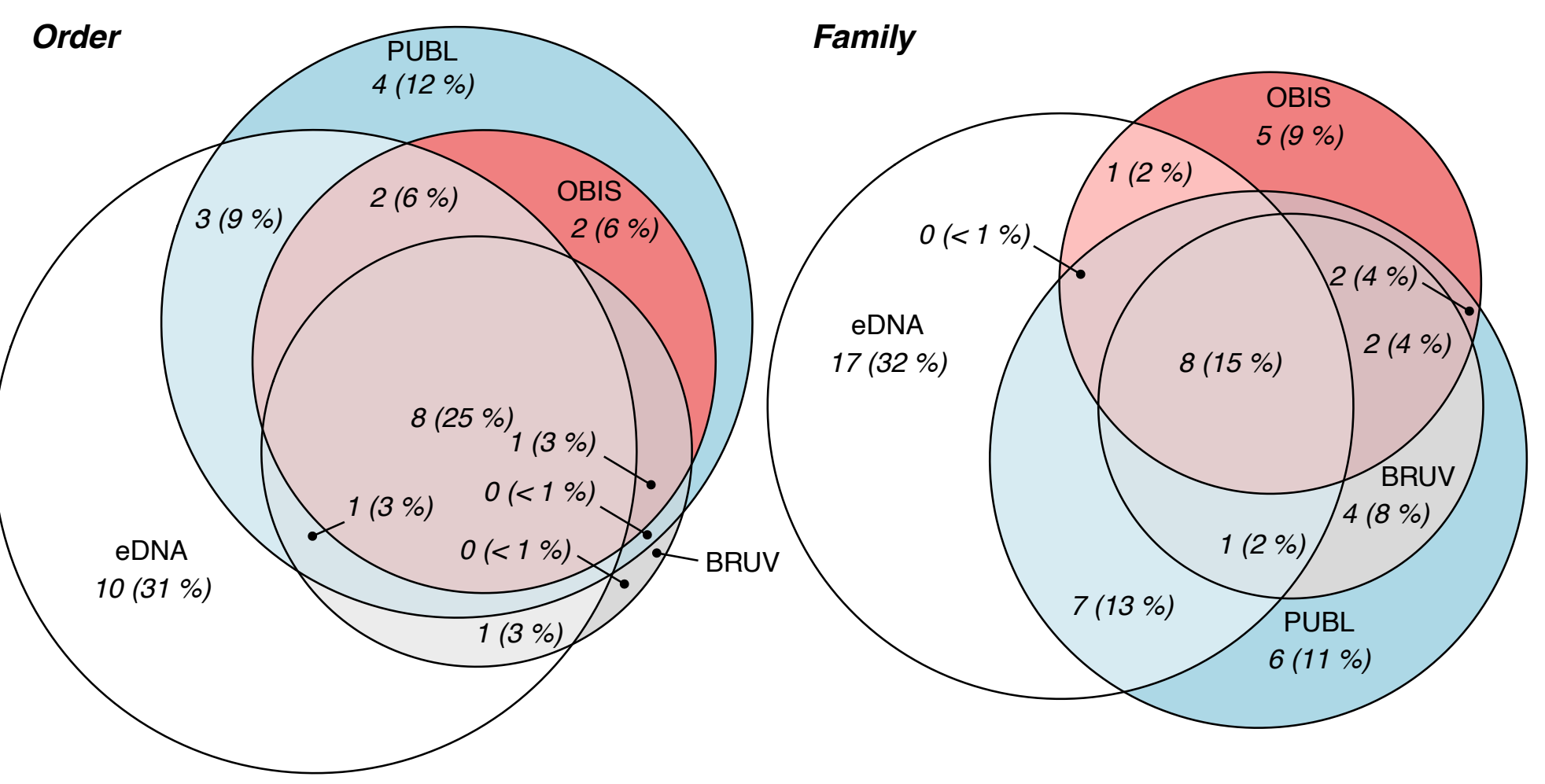

\section{Genus}

\section{Species}
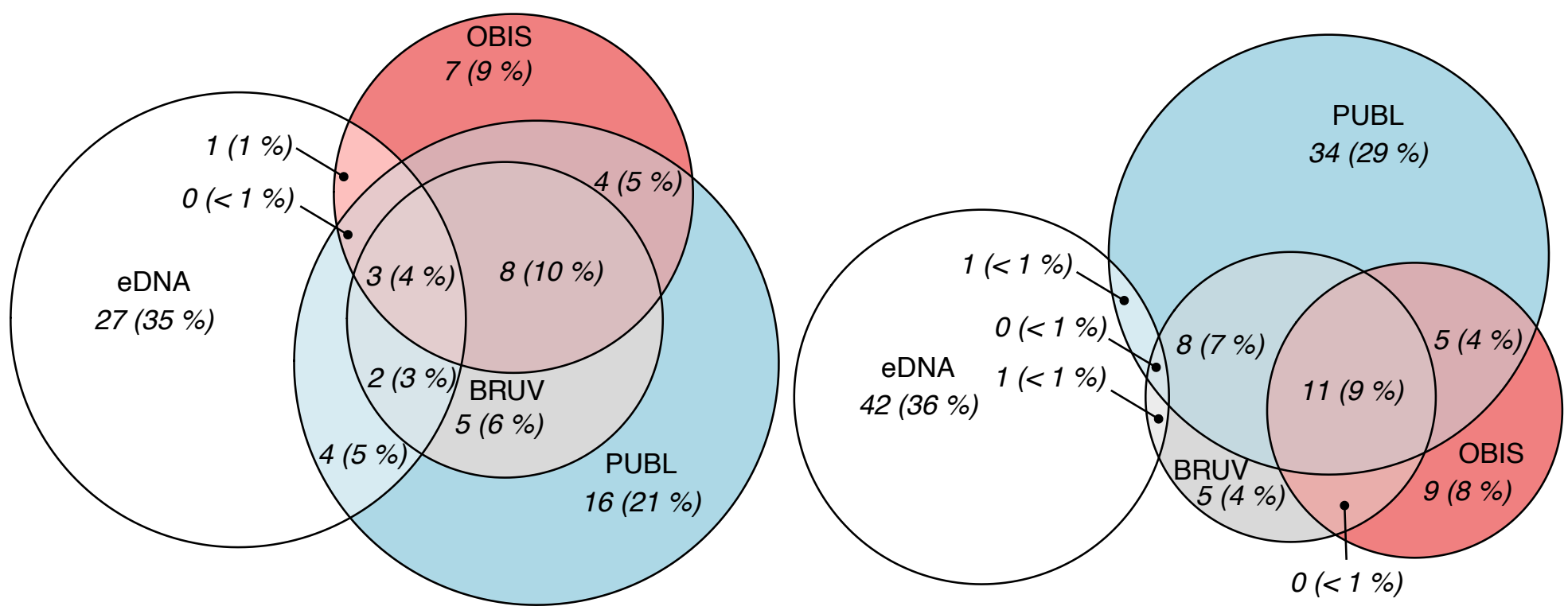